www.jmscr.igmpublication.org

Impact Factor (SJIF): 6.379

Index Copernicus Value: 71.58

ISSN (e)-2347-176x ISSN (p) 2455-0450

crossref DOI: https://dx.doi.org/10.18535/jmscr/v6i6.105

Journal Of Medical Science And Clinical Research

IGM Publication

An Official Publication of IGM Publication

\title{
Two Novel C-Terminal Frame shift Mutations in the CYB5R3 Gene Lead to Global Growth and Developmental Delay Associated with Recessive Congenital Methemoglobinemia Type II
}

\begin{abstract}
Authors
Vinod Gupta $^{1}$, Rati Devendra ${ }^{1}$, Aruna Rajendran ${ }^{2}$, Neeraj Sidharthan ${ }^{3}$

Prashant Warang Prabhakar Kedar ${ }^{1}$

${ }^{1}$ National Institute of Immunohematology (Indian Council of Medical Research), K.E.M Hospital Campus,

Parel, Mumbai-40012, India

${ }^{2}$ Sri Ramchandra Medical College and Research Institute Porur, Chennai-600116 Tamilnadu, India

${ }^{3}$ Dept. of Medical Oncology, Amrita Institute of Medical Sciences, Edappally, Kochi-682041 Kerala India

Corresponding Author

Dr Prabhakar S Kedar, PhD

Scientist D, National Institute of Immunohaematology, Indian Council of Medical Research

$13^{\text {th }}$ Floor, New Multistoried Building, K.E.M Hospital Campus, Parel, Mumbai 400012, India

Tel: + 9122 24138518, Fax: + 9122 24138521, Email: kedarps2002@yahoo.com

Abstract

Deficiency of $\mathrm{NADH}$-cytochrome $b 5$ reductase is the rare cause of recessive congenital methemoglobinemia (RCM) Type-II. It is associated with the mild cyanosis and mental retardation. We have identified three new patients with RCM type-II due to NADH-cytb5r deficiency due and also offered the prenatal diagnosis. All three index cases had cyanosis with severe progressive neurological dysfunction. Methemoglobin level was found in the range of $34.0 \%$ to $65 \%$ and red blood cell NADH-cytb5r activity were detected only 5 to $30 \%$ of normal. The clinical pictures were very similar in all three cases, with severe encephalopathy, microcephaly, generalized dystonia, movement disorders and severe cyanosis. The neurological prognoses are poor; in particular, all the patients do not walk or speak. DNA sequencing result identified two novel mutations. In the first case identified homozygous 2-bp deletion in exon 7 of the CYB5R3 gene, noted as c.604_605delCT (p.Thr202SerfsX98) and in the second case also discovered frame shift homozygous 3-bp deletion mutations (c.766_768delGAG) in exon 9 result in loss of Glutamic acid at codon 256. Third cases showed splice site homozygous mutation (p.Gly76Ser) first time associated with RCM II. Prenatal diagnosis of the fetus in this family revealed same homozygous mutation p.Gly76Ser.

Keywords: Recessive congenital methemoglobinemia (RCM) type II, NADH-cyb5r deficiency, Neurological disorders.
\end{abstract}

\section{Introduction}

Recessive Congenital methemoglobinemia (RCM) is an autosomal recessive metabolic disorder due to NADH-cytochrome b5 reductase (NADHcyb5r) deficiency. NADH-cyb5r deficiency also known as NADH-methemoglobin reductase or Diaphorase-1, is a flavin adenine dinucleotide (FAD) containing enzyme catalyzing electron transfer from $\mathrm{NADH}$ to cytochrome $\mathrm{b} 5^{[1-3]}$. In human, NADH-cyb5r enzyme produces two 
protein variants. A soluble form is present predominantly in erythrocytes and a membranebound form is localized to the endoplasmic reticulum (ER), mitochondria, nuclei, peroxisomes and plasma membranes of somatic cells. The soluble erythrocytic cytb5r isoenzyme is involved in methemoglobin reduction, while the membrane-bound isoform of NADH-cyb5r is localized to the endoplasmic reticulum and outer mitochondrial membrane whereas soluble form is found in erythrocytes ${ }^{[4-5]}$. Two clinical types of RCM (type I and II) have been defined. Type I $\mathrm{RCM}$ is a benign hereditary form of methemoglobinemia in which cyanosis is the only clinical sign, in which; cyanosis is due to the chocolate-brown colour of blood caused by the chronically high erythrocytic methemoglobin level. Cyanosis may be very difficult to detect in this setting, however. The complexion is described as pale or greyish-blue. Cyanosis will be only seen on the mucosae and nails in darkskinned patients, and this may explain the apparent lack in Indian patients. The cyanosis is enhanced during stressful events such as birth and infection and may remain unnoticed for years. Yet, cyanosis is the most helpful diagnostic sign for $\mathrm{RCM}^{[6]}$. Cyanosis is mainly corrected by administration of methylene blue, or ascorbic acid and riboflavin ${ }^{[7]}$. In contrast, the less frequent type II methemoglobinemia is associated with generalized NADH-cyb5r deficiency affecting all cells and is characterized by severe cyanosis with neurologic disability and numerous developmental defects, the affected child usually dies at an early age but an oldest reported case of type II are seen survived up to 20 years. In type II RCM, permanent moderate to severe cyanosis is associated with neurological manifestations, including mental retardation, microcephaly, and generalized dystonia and movement disorders. Type II RCM was subsequently shown to be characterized by a profound enzyme deficiency in all tissues, involving both the soluble and membrane-bound NADH-cyb5r isoforms ${ }^{[8-10]}$.
NADH-cyb5r activity is controlled by CYB5R3 gene, which is localized on chromosome 22q13qter (Gene ID: 1727) and contains nine exons ${ }^{[11]}$. To date, more than 60 mutations have been identified in the CYB5R3 gene causing type I (35 mutations) and II RCM (35 mutations) ${ }^{[12]}$. The genotype-phenotype relationship is extensively discussed in recent papers ${ }^{[13-14]}$. Disruptive mutations, such as splicing, stop codon or frameshift mutation are greatly affecting the catalytic activity of the enzyme, resulting in a global loss of both the membrane-bound and soluble forms, and are associated with the severe Type-II disease ${ }^{[9,15]}$. Some mutations have been identified in both Types-I and Type-II RCM suggests that the clinical manifestations in compound heterozygotes are determined by the combination of cytb5r enzymatic activities of the two variants. Mutations causing enzyme instability lead to type I RCM, whereas mutations that inactivate the enzyme are associated with type II RCM (Table-1) ${ }^{[13]}$. In this study, we performed direct Sanger's sequencing in three families with neurological defects and discovered two novel homozygous mutations and one reported mutation first time found in homozygous form in Indian RCM Type-II patients. These include homozygous 2-base pair (bp) deletion in exon 7 of the CYB5R3 gene, noted as c.604_605delCT (p.Thr202SerfsX98) in the first case and another frame-shift homozygous mutation c.766_768delGAG 3-bp deletion in exon 9 with loss of Glu256 (p.Glu256Del) in the second case, one homozygous mutation p.Gly76Ser in the third case found first time in Indian RCM type II patient and all are having severe global neurologic impairments.

\section{Patients, Material, and Methods Clinical reports \\ Family-A}

The proband, 2 years baby is the only child of Family-A born to consanguineous parents. A first pregnancy ended with an abortion at the fourth months. The index case was born at term after 
uneventful pregnancy and delivery, and her birth weight was $2.25 \mathrm{Kg}$. There was no familial history. The pregnancy and delivery were normal. At birth, her weight and head circumference were -1.5 SD. At age 14 days, she had frequent vomiting and became cyanotic when crying. Since the first days of the life of the baby appeared cyanotic, but respiratory and cardiac functions were normal. During the first months of life, feeding difficulties, failure to thrive, psychomotor development delay and particularly a persistent slate-gray cyanosis suggested the presence of methemoglobinemia. Therapy with ascorbate did not improve her neurological conditions; when we first observed her, at 1 year of age, she had a severe spastic and dystonic quadriparesis with hyperkinetic involuntary movements, severe microcephaly, and very simple and primitive reactions to environmental changes. After a few months, generalized tonic seizures and myoclonic jerks ensued, which were not responsive to the common antiepileptic drugs. The electroencephalographic examination showed a slow and irregular basal activity with extremely frequent and periodic paroxysmal burst spike-wave complexes during sleep. A computed-tomography scan revealed diffuse brain atrophy. The patient is now 2 years old and referred to NIIH for a complete investigation of methemoglobinemia and severe global neurologic impairments.

\section{Family-B}

The second proband is a 10-year-old Muslim boy born full-term at home to a 26-year-old mother who was married to close cousin. There was no familial history. The pregnancy and delivery were normal. At birth, his weight and head circumference were -1.5 SD. Diffuse cyanosis was noted at birth, and he was hospitalized for 10 days. He had permanent mild cyanosis, which was more prominent on the labial mucosa and nails and worsened when he cried. Severe growth retardation and global neurologic impairments were noted in infancy. Patient has never been able to roll over, sit independently, crawl, or walk. Physical examination is notable for no facial dysmorphism, body odors, or skin findings except cyanosis and a diffuse eczematous, excoriated rash. The sensation is grossly intact to touch and pain throughout all limbs whereas no family members have sign and symptoms of neurologic problems. Hematological parameters were tested many times where complete blood count with differential was always normal, including hemoglobin of $13 \mathrm{~g} / \mathrm{dL}$. Hemoglobin electrophoresis was normal with $98 \% \mathrm{Hb}-\mathrm{A}$ and $2 \% \mathrm{Hb}-\mathrm{A}_{2}$. Methemoglobin was also measured and noted always in the elevated range; ascorbic acid therapy started and resulted in a slight decrease of methemoglobinemia, with no effect on neurological symptoms. Karyotype analysis of peripheral blood revealed 46, XY without any chromosomal abnormalities. Brain magnetic resonance imaging (MRI) demonstrated no focal abnormalities with diffuse atrophy and decreased white matter. The patient was on ascorbic acid therapy with $500 \mathrm{mg}$ of oral ascorbic acid per day. With this history, the proband was referred to our unit for further workup for methemoglobinemia.

\section{Family-C}

This patient is a three-year-old Indian Muslim girl born to consanguineous parents with unremarkable birth history. She presented with recurrent afebrile convulsion since 4-month-old and electroencephalogram (EEG) revealed abnormal left temporal spike waves. No structural abnormality was identified by computed tomography (CT) of the brain. Piracetam, gabapentin and amino acid supplements were given to the patient but they all failed to control the seizure. The patient was admitted at 6-monthold for further management. She was observed a complaint of inability to hold neck. Her head circumference was $47 \mathrm{~cm}$ (97th percentile), body weight was $7.1 \mathrm{~kg}$ (2nd-10th percentile) and body height was $61 \mathrm{~cm}$ (b3rd percentile). At the age of 1 year, she was investigated for global growth and developmental delay. Laboratory investigations for complete blood count, liver and renal function tests, and blood random glucose, ammonia and uric acid levels were all unremarkable whereas 
hemoglobin was $19.9 \mathrm{~g} / \mathrm{dl}$ and methemoglobin level was detected $47.5 \%$. Some of the blood parameters including blood gas analysis revealed pH-7.43, pCO2-22.9mmHg, pO2-91.7 mmHg, cHCO3 $15.0 \mathrm{mmol} / \mathrm{L}$. with this past investigation, patient was referred to NIIH for details study.

\section{Ethical approval and consent}

The study has been carried out in accordance with the research rules of our institutional ethical committee on human experimentation. This study has been approved by the National Institute of Immunohematology Ethical committee and as per protocol, written informed consents were obtained from all the patients or their parents.

\section{Blood sample}

Informed consent was obtained from their parents. Peripheral blood was collected and leukocytes were separated using the Histopaque density gradient method (Sigma-Aldrich, Inc. St.Louis MO, USA). Genomic DNA was isolated from peripheral blood leukocytes by phenol/chloroform extraction according to standards protocols also genomic DNA (gDNA) was isolated using Qiagen DNA extraction kit according to the manufacturer's instructions.

\section{Methemoglobin estimation and NADH-Cyb5R Enzyme assay}

Complete blood counts were measured by automated hematology analyzer XN (Sysmex, Kobe, Japan). The methemoglobin level was measured using potassium ferricyanide method immediately after blood collection and NADHcytochrome b5 reductase (NADH:cyb5r) activity was measured following oxidation of NADH at $340 \mathrm{~nm}$ on an Analytic JENA Spectrophotometer for 10 minutes at $30{ }^{\circ} \mathrm{C}$ (Analytical JENA, Germany) [16]. Reactions were monitored at 1minute intervals for $10 \mathrm{~min}$. and a rate was determined from the linear portion of the curve, rates were calculated using a linear regression model. Each reaction contained $100 \quad \square 1$ hemolysate, $2 \mathrm{mM}$ potassium ferricyanide
$\left(\mathrm{K}_{3} \mathrm{Fe}(\mathrm{CN})_{6}\right), 1 \mathrm{mM}$ Tris- $\mathrm{HCl} \mathrm{pH} 8.0,0.5 \mathrm{mM}$ EDTA and $0.2 \mathrm{mM}$ NADH [17].

\section{Polymerase chain reaction (PCR) and Sanger sequencing}

Extracted genomic DNA from each sample was subjected to PCR, amplified flanking of all 9 exons using a set of primers. Amplified PCR products were gel purified and directly sequenced in both directions. All PCR reactions were carried out with the TaKaRa Taq DNA Polymerase and Premix Taq DNA Polymerase Kit (Cat. \#R006A) (TAKARA Japan) in a final a final volume of 20 $\mu \mathrm{L}$ containing $20 \mathrm{ng}$ of genomic DNA, Takara Buffer $1 \times, \mathrm{MgCl} 2,1.5 \mathrm{mM}$, dNTPs $0.2 \mathrm{mM}, 0.5$ $\mathrm{U}$ of TaKaRa Taq DNA Polymerase and $10 \mathrm{pmol}$ of both forward and reverse primers. DNA samples were denatured at $95{ }^{\circ} \mathrm{C}$ for $5 \mathrm{~min}$ and then amplified for 35 cycles as follows: $95{ }^{\circ} \mathrm{C}$ for $20 \mathrm{~s}$, annealing at $58{ }^{\circ} \mathrm{C}$ for $20 \mathrm{~s}, 72{ }^{\circ} \mathrm{C}$ for $20 \mathrm{~s}$; and a final extension at $72{ }^{\circ} \mathrm{C}$ for $7 \mathrm{~min}$. PCR product was QIAquick PCR Purification Kit (cat. nos. 28104 and 28106). Sequencing reactions were performed using the BigDye Terminator v3.1 Cycle Sequencing Kit on a 3730 DNA Analyzer (Applied Biosystems) [12]. Nucleotide sequences of the 9 exons were obtained from the Gen Bank database accession numbers M28705 to M28713), and the following primers were designed: EX1F: 5'-gcgacagagcgagcgcggcg-3',; EX1R: 5'-gtcacctcccgcaggccaac-3',; EX1SF: 5'cattctgagccaggcctcctgg-3',; EX1SR: 5_-ctgttctaaccgggaggaagtg-3'; EX2F: 5'-ctttctggatgagggtggtg-3'; EX2R: 5'-gaggcagtgagtgtggttca-3'; EX3F: 5'-gttctggccthe accttgtttgt-3',; EX3R: 5'ccttccactctcattccaa-3',; EX4F: 5'-caggccaggctttgaatg-3'; EX4R: 5'-cccttctttggcttttgttg-3'; EX5F: 5'-gtacacgaggctggtggttt-3'; EX5R: 5'-agctggcctgacgagagtc-3'; EX67F: 5'-cctctacctcggacctcaca3'; EX67R: 5'-gtcatccccagaatctcagc-3'; EX8F: 5'gagtccctcctgaaagctc-3'; EX8R: 5'-gaaaggactctgcctctgga-3';

EX9F: 5'-gggatcagcctctccattct-3'; EX9R: 5'ggcaggacgtactctgaagg-3'; 


\section{Results and Discussion}

All the three index patients are concerns with the cyanosis with a severe neurologic disability. These cases were referred to our Institution for routine measurements of methemoglobin level and red blood cell enzyme activities because NADH cytochrome b5 reductase deficiency was known to segregate in the RCM type II. The hematological, biochemical, and molecular data of three families are summarized in Table-1. The methemoglobin level ranges from 34.0 to $65.0 \%$ and $\mathrm{NADH}-$ Cyb5R enzymatic activity was found to be between 8.4 to $9.0 \mathrm{IU} \mathrm{gm} / \mathrm{Hb}$ (Normal range$35 \pm 5 \mathrm{IU} / \mathrm{gm} \mathrm{Hb}$ ) and both parents and some other family members have intermediate activity (Intermediate-range- 18.5 to $25.6 \mathrm{IU} / \mathrm{gm} \mathrm{Hb}$ ). There were total 20 members in these three families were detected as a carrier for $\mathrm{NADH}$ Cyb5R deficiency associated with three index cases based on intermediate enzyme activity and heterozygous mutation (Figure-1). In our study, all the patients were diagnosed after cyanosis was prominent. Failure to detect cyanosis may delay the diagnosis. For example, first two patients were diagnosed at age 2 years when cyanosis became obvious because of a pulmonary infection. The clinical pictures were very similar in all three cases, with severe encephalopathy, microcephaly, generalized dystonia, movement disorders and mild cyanosis usually reported in RCM type II cases ${ }^{\mathbf{1 6}}$. The neurological prognoses are poor; in particular, all the patients do not walk or speak. The diagnosis was confirmed by very low cytb5r activity in the red blood cells. DNA sequencing result identified a novel homozygous 2-bp deletion in exon 7 of the CYB5R3 gene, noted as c.604_605delCT (p.Thr202SerfsX98) in the first case and frameshift homozygous 3-bp deletion mutations c.766_768delGAG in exon 9 with loss of Glutamic acid at codon 256 (p.Glu256Del) in the second case and also third cases showed splice site homozygous mutation (p.Gly76Ser) first time associated with RCM II ${ }^{[17]}$ (Figure-2). In order to distinguish between type, I and II RCM, level of NADH-cytb5r activity were correlated with the clinical presentation as all are having severe global neurologic impairments ${ }^{[13]}$. In benign type I $\mathrm{RCM}$, the activity of the soluble form of NADHcytb5r is decreased only in erythrocytes but in type II RCM, cytb5r activity is strongly diminished in both cell types, confirming the generalized cytb5r deficiency diagnosed type II RCM in our patients with cyanosis and severe psychomotor retardation ${ }^{[18]}$. All these patients, elevated methemoglobinemia were associated with 5 to $30 \%$ of normal cytb5r activity in erythrocytes, while activity was not measured in leucocytes. The two mutations identified in the CYB5R3 gene p.Thr202SerfsX98 and p.Glu256Del has been found first time in type II Indian RCM patients in the homozygous state and also p.Gly76Ser in the homozygous state first time causing RCM II which was earlier reported in the compound heterozygous state with p.val253Met by Percy et $\mathrm{al}^{[16]}$. There are only six cases of recessive congenital methemoglobinemia (RCM) type II reported from India in the last 10 years. Their genotype-phenotype relationships were discussed in our earlier paper. Out of these six cases, the molecular characterization was done in four cases where nonsense mutations and splicesite mutations were detected ${ }^{[12-13]}$.

To date, 35 different mutations have been identified in type II RCM. Mostly they lead to altered splicing, disruption of the active site of the enzyme or premature truncation of the protein (Table-2) ${ }^{[11]}$. The enzyme is thus inactive in both it's soluble and membrane-bound forms in all cell types. The two novel mutations described here are in keeping with this pattern. In our patient 1 and 2, the novel homozygous p.Thr202SerfsX98 and p.Glu256Del deletion in the exon 6 and 9 alters the consensus sequence of the frameshift and causes in-frame exon 6 and 9 skipping respectively. The frameshift after exon 6 and exon 9 suggests severe consequences at the protein level. The soluble form of the enzyme, translated from the ATG start site within exon 6 and exon 9, should be here completely absent, while the function of the membrane-bound form of the 
enzyme lacking the amino acids after pThr202 in exon 6 and p.Glu256 in exon 9 is probably seriously affected. Indeed, at birth this patient had marked generalized persistent cyanosis with a methemoglobin level of 53\%; no enzyme activity was detected in erythrocytes at age 1 year.

In our study, case-3 is from western Maharashtra had a homozygous the p.Gly76Ser mutation, which was previously reported in combination with p.Leu131Pro, and p.Val253Met led to a severe type II RCM phenotype ${ }^{[17]}$. This provides an additional example of mutations in the CYB5R3 gene that homozygous the Gly76Ser mutation itself will be associated with type II RCM. The resulting RCM phenotype is determined by the combination of the double allelic mutations and the final enzyme conformation. The resulting general deficiency in NADH-cyb5r activity is in keeping with the observed type II RCM phenotype. It is also reported that the p.Gly76Ser variant had only $51 \%$ of the catalytic efficiency of the wild-type enzyme whereas the p.Gly76Ser mutation, in combination with Leu131Pro, led to a severe type II RCM phenotype. The nature of the mutations can also be important for the RCM phenotype as in our cases, the absence of functional protein may, therefore, account for the severe RCM Type-II clinical pattern observed in homozygous patients [3]

In occasion of the second pregnancy in a family of case-3, prenatal diagnosis was offered to this family with p.Gly76Ser homozygous mutation and history of consanguinity and due to the $25 \%$ recurrence risk of recessive congenital methemoglobinemia type II. Prenatal Diagnosis was performed via CVS for the diagnosis of RCM-II. Genomic DNA was prepared from CVS sample taken by ultrasound-mediated chorionic villus at 12 weeks gestation. Molecular analysis confirmed homozygosity for p.Gly76Ser mutation in the CVS sample, therefore in these circumstances, treating doctor recommend immediate termination of pregnancy. So in this way, we prevented through prenatal diagnosis in affected families, owing to its severity and $25 \%$ recurrence rate. Prenatal diagnosis can be based on molecular assay in chorionic villus biopsy, is a test performed during pregnancy to determine if an unborn child is at risk for congenital defects like RCM type-II. Molecular prenatal diagnosis is reliable and can be done at an early stage of pregnancy, but only if the mutation in the $C Y B 5 R 3$ gene has been identified in each family at risk. The molecular prenatal diagnosis was successfully performed first time in the Indian family of RCM II which previously reported by Leroux et al., in 2005 and now routinely done in many laboratories [18]

We reviewed neurological features in the 32 earlier reported cases, in most cases, during the first 2 months of life, $44 \%$ of patients had a normal neurological examination. The full clinical phenotype manifested at about 6-9 months of life. Fixed encephalopathy was always present and extremely severe ${ }^{[19]}$. All the patients, including our 23-year-old patient, had psychomotor skills inferior to those of a 1-year-old child. At best, the patients could sit, grip objects in a dystonic palmar manner, react and smile at familiar faces and utter sounds. None of the patients walked or spoke. All the patients had generalized dystonia and axial hypotonia, sometimes associated with occasional dystonic storms and opisthotonos. Dystonia and movement disorders were mainly visible after age 6 months when axial tone tended to improve. Spontaneous gesticulation was reported as permanent and uncoordinated, with proximo-distal and choreo-athetoid involuntary movements. These latter tend to decrease with aging, as usual in post-anoxic and metabolic movement disorders. Microcephaly was always present and progressive. This feature is nonspecific but reveals severe brain developmental deficiency. Growth retardation is frequent but inconsistent and is worsened by feeding difficulties associated with swallowing disturbances. However, none of the patients needed enteral nutrition, and vomiting gradually disappeared in our eldest patients. Strabismus was 
reported in $88 \%$ of cases. Behavior abnormalities, such as frequent screaming and agitation, were reported in the first years of life. It is difficult to determine whether these are genuine behavioral disturbances or whether they result from movement disorders. Most of the cases also showed severe skeletal deformations such as scoliosis and musculotendinous retractions, likely due to chronic generalized dystonia ${ }^{[13,20]}$.

The identification of molecular mutations within the $C Y B 5 R 3$ gene can contribute to understanding the clinical phenotype of recessive congenital methemoglobinemia. Missense mutations that reduce enzyme stability without affecting the catalytic function result in RCM type-I symptoms confined to red cells, which cannot replace the degraded protein. Conversely, disruptive mutations (splicing, nonsense, frameshift) or mutations that markedly reduce catalytic activity, affect all cells expressing NADH-cyb5r enzyme and result in the Type-II disease. Total sixty-seven different mutations of $C Y B 5 R 3$ gene have been so far reported in 58 unrelated patients (31 Type-I and 36 Type-II). All the mutations are located in exons two to nine and the majority are missense. We describe the clinical and molecular features of 3 newly diagnosed patients with recessive congenital methemoglobinemia type II. We found 2 novel mutations and one homozygous mutation first time in Indian families. The molecular prenatal diagnosis was successfully performed for the first time in the Indian family of RCM II.

Table-1: Hematological, biochemical and molecular characteristics of three new families with Type-II recessive hereditary methemoglobinemia due to NADH-cytochrome $b 5$ reductase deficiency.

\begin{tabular}{|c|c|c|c|c|c|c|c|c|c|c|}
\hline \multirow{2}{*}{$\begin{array}{l}\text { Sr. } \\
\text { No. }\end{array}$} & \multirow[t]{2}{*}{ Parameters } & \multicolumn{3}{|c|}{ FAMILY-A } & \multicolumn{3}{|c|}{ FAMILY-B } & \multicolumn{3}{|c|}{ FAMILY-C } \\
\hline & & Index case-1 & Father & Mother & Index case-2 & Father & Mother & Index case-3 & Father & Mother \\
\hline 1 & Age/Sex & $\begin{array}{c}2 \mathrm{yrs} / \\
\text { Female }\end{array}$ & $\begin{array}{l}31 \mathrm{yrs} / \\
\text { Male }\end{array}$ & $\begin{array}{l}\text { 26yrs/ } \\
\text { Female }\end{array}$ & $\begin{array}{l}\text { 10yrs/ } \\
\text { Male }\end{array}$ & $\begin{array}{c}\text { 39yrs/Mal } \\
\text { e }\end{array}$ & $\begin{array}{c}35 \mathrm{yrs} / \\
\text { Female }\end{array}$ & $\begin{array}{c}3 \mathrm{yrs} / \\
\text { Female }\end{array}$ & $\begin{array}{l}32 \mathrm{yrs} / \\
\text { Male }\end{array}$ & $\begin{array}{c}\text { 29yrs/ } \\
\text { Female }\end{array}$ \\
\hline 2 & $\mathrm{Hb}(\mathrm{g} / \mathrm{dl})$ & 11.8 & 15.7 & 14.9 & 11.7 & 13.5 & 12.1 & 11.9 & 16.0 & 13.4 \\
\hline 3 & WBC $\left(\mathrm{X} \times 10^{3} / \square \mathrm{L}\right)$ & 9.4 & 8.9 & 10.2 & 5.8 & 6.2 & 7.8 & 9.1 & 7.7 & 9.3 \\
\hline 4 & $\mathrm{RBC}\left(\mathrm{X} \times 10^{6} / \square \mathrm{L}\right)$ & 6.50 & 5.50 & 5.22 & 4.93 & 4.95 & 4.86 & 6.64 & 5.5 & 4.94 \\
\hline 5 & HCT (\%) & 42.7 & 46.3 & 43.2 & 41.1 & 39.6 & 38.9 & 44.8 & 46 & 39.6 \\
\hline 6 & $\mathrm{MCH}(\mathrm{pg})$ & 18.2 & 28.5 & 28.5 & 23.7 & 28.2 & 29.2 & 17.9 & 29.1 & 27.1 \\
\hline 7 & MCHC $(\mathrm{g} / \mathrm{dl})$ & 27.6 & 33.9 & 34.5 & 28.5 & 34.5 & 33.4 & 26.6 & 34.8 & 33.8 \\
\hline 8 & Meth-Hb (\%) & 65.0 & 6.5 & 4.0 & 34.0 & 1.4 & 6.2 & 39.4 & 6.5 & 6.2 \\
\hline 9 & $\begin{array}{c}\text { NADH-Cyb5R activity } \\
\text { (IU/gHb) }\end{array}$ & 8.40 & 21.5 & 18.5 & 8.66 & 25.6 & 21.8 & 9.0 & 23.6 & 22.4 \\
\hline 10 & Mutation cDNA nt change & \multicolumn{3}{|c|}{ c.606_607delCT ( Novel) } & \multicolumn{3}{|c|}{ c.766_768delGAG (Novel) } & \multicolumn{3}{|c|}{ c. $226 \mathrm{G}>\mathrm{A}$} \\
\hline 11 & Amino acid change & \multicolumn{3}{|c|}{ p.Thr202SerfsX98 } & \multicolumn{3}{|c|}{ p.Glu256del } & \multicolumn{3}{|c|}{ p.Gly76Ser } \\
\hline & & Homo & Hetero & Hetero & Homo & Hetero & Hetero & Homo & Hetero & Hetero \\
\hline
\end{tabular}

RBC; red blood cells, WBC: white blood cells, PLT; Platelet (NADH-Cytb5R Normal range- $35 \pm 5$ IU/gm Hb)

Table-2: List of Mutations reported in CYB5R3 gene associated with Type II recessive congenital methemoglobinemia.

\begin{tabular}{|c|c|c|c|c|c|c|}
\hline $\begin{array}{l}\text { Sr. } \\
\text { No. }\end{array}$ & $\begin{array}{l}\text { HGVS nomenclature } \\
\text { for cDNA nt change }\end{array}$ & $\begin{array}{l}\text { Exon or } \\
\text { [Intron] }\end{array}$ & $\begin{array}{c}\text { HGVS nomenclature } \\
\text { for amino acid } \\
\text { change }\end{array}$ & $\begin{array}{c}\text { Accompanying } \\
\text { mutation HGVS } \\
\text { nomenclature }\end{array}$ & 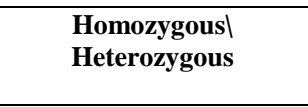 & Reference \\
\hline 1. & c. $129 \mathrm{C}>\mathrm{A}$ & 2 & p.Tyr43X & p.Pro96His & Compound Heterozygous & Manabe et al(1996)[21] \\
\hline 2. & c. $173 \mathrm{C}>\mathrm{G}$ & 3 & p.Arg58Pro & p.Arg58Pro & Homozygous & Puffenberger et al 2012[27] \\
\hline 4. & c. $226 \mathrm{G}>\mathrm{A}$ & 3 & p.Gly76Ser & p.Val253Met & Compound Heterozygous & Percy et al (2006a) [17] \\
\hline 5. & c.226G $>A$ & 3 & p.Gly76Ser & p.Gly76Ser & Homozygous & This Paper \\
\hline 6. & c. $229 \mathrm{C}>\mathrm{T}$ & 4 & p.Gln77X & p.Arg160X & Compound Heterozygous & Aalfs et al (2000) [16] \\
\hline 10. & c. $379 A>G$ & 5 & p.Met127Val & c. $418-2 \mathrm{~A} \rightarrow \mathrm{G}$ & Compound Heterozygous & Kugler et al (2001) [3] \\
\hline 11. & c. $382 \mathrm{~T}>\mathrm{C}$ & 5 & p.Ser128Pro & p.Ser128Pro & Homozygous & Kobayashi et al(1990) [25] \\
\hline 12. & c. $392 \mathrm{~T}>\mathrm{C}$ & 5 & p.Leu131Pro & p.Gly76Ser & Compound Heterozygous & Ewenczyk et al (2008) [19] \\
\hline 13. & c. $478 \mathrm{~A}>\mathrm{T}$ & 6 & p.Arg160X & p.Gln77X & Compound Heterozygous & Aalfs et al (2000) [16] \\
\hline 14. & c.606_607delCT & 6 & p.Thr202SerfX98 & p.Thr202SerfX98 & Homozygous & This paper \\
\hline 15. & c. $611 \mathrm{G}>\mathrm{A}$ & 7 & p.Cys204Tyr & p.Cys204Tyr & Homozygous & Manabe et al 1996 [21] \\
\hline
\end{tabular}




\begin{tabular}{|c|c|c|c|c|c|c|}
\hline 16. & c. $610 \mathrm{~T}>\mathrm{C}$ & 7 & p.Cys204Arg & p.Met273del & Compound Heterozygous & Vieira et al (1995) [22] \\
\hline 17. & c. $610 \mathrm{~T}>\mathrm{C}$ & 7 & p.Cys204Arg & p.Cys204Arg & Homozygous & Maran et al (2005) [26] \\
\hline 18. & c. $655 \mathrm{C}>\mathrm{T}$ & 8 & p.Arg219X & p.Arg219X & Homozygous & Vieira et al (1995) [22] \\
\hline 19. & c. $708 \mathrm{G}>\mathrm{A}$ & 8 & p.Trp236Ter & p.Trp236Ter & Homozygous & Warang P. et al 2015 [12] \\
\hline 20. & c. $721 \mathrm{~A}>\mathrm{G}$ & 8 & p.Arg241Gly & p.Arg241Gly & Homozygous & Toelle et al (2004) [28] \\
\hline 21. & c. $757 \mathrm{G}>\mathrm{A}$ & 9 & p.Val253Met & p.Val253Met & Homozygous & Kugler et al (2001) [3] \\
\hline 22. & c.766_768delGAG & 9 & p.Glu256del & p.Glu256del & Homozygous & This paper \\
\hline 23. & c.815_817del & 9 & p.Met273del & p.Cys204Arg & Compound Heterozygous & Vieira et al (1995) [22] \\
\hline 24. & c.882_884delinsAA & 9 & p.Thr295fsX & p.Thr295del & Homozygous & Leroux et al (2005) [9] \\
\hline 25. & c.895_897del & 9 & p.Phe299del & p.Phe299del & Homozygous & Shirabe et al (1994) [29] \\
\hline 26. & IVS $5 \mathrm{ds}+8 \mathrm{G}>\mathrm{C}$ & Intron 5 & Loss of exon 5 & p.Met127Val & Homozygous & Kugler et al (2001) [3] \\
\hline 27. & IVS 5 as $-2 \mathrm{~A}>\mathrm{C}$ & Intron 5 & Loss of exon 6 & c.548 & Homozygous & Owen et al (1997) [6] \\
\hline 28. & IVS $5-2 \mathrm{~A}>\mathrm{C}$ & Intron 5 & Loss of exon 6 & c. 548 & Homozygous & Maran et al (2005) [26] \\
\hline 29. & IVS $5 \mathrm{ds}+2 \mathrm{~T}>\mathrm{C}$ & Intron 5 & Mis-splicing of exon 5 & c. $547+2 \mathrm{~T}>\mathrm{C}$ & Homozygous & Yilmaz et al (2005) [23] \\
\hline 30. & IVS 4 as $-2 A>G$ & Intron 5 & Loss of exon 5 & c. $547+8 \mathrm{G}>\mathrm{C}$ & Homozygous & Vieira et al (1995) [22] \\
\hline 31. & IVS 8 as $-1 \mathrm{G}>\mathrm{T}$ & Intron 8 & Mis-splicing of exon 9 & c. $818-1 \mathrm{G}>\mathrm{T}$ & Homozygous & Shirabe et al (1995) [7] \\
\hline 32. & IVS $2 \mathrm{ds}+1 \mathrm{G}>\mathrm{A}$ & Intron 2 & Skipping of Exon.2 & IVS 2 ds $+1 \mathrm{G}>\mathrm{A}$ & Homozygous & Ewenczyk at al 2008 [19] \\
\hline 33. & $\begin{array}{c}\text { c.517_525 AAG TCT } \\
\text { GTG del }\end{array}$ & 6 & $\begin{array}{l}\text { p.Lys173-Ser174- } \\
\text { Val175del }\end{array}$ & $\begin{array}{c}\text { p.Lys173-Ser174- } \\
\text { Val175del }\end{array}$ & Homozygous & Warang P. et al 2015 [12] \\
\hline 34. & c.562_564del & 7 & p.Leu188del & p.Leu188del & Homozygous & Puffenberger et al 2012 [27] \\
\hline 35. & c.22 1320_633+1224del & $2-7$ & Loss of exon 2-7 & $\begin{array}{c}\text { c.22 1320_633 } \\
+1224 \mathrm{del}\end{array}$ & Homozygous & Higasa et al 1998 [24] \\
\hline
\end{tabular}

Figure 1: Pedigree of three families with Recessive Congenital Methemoglobinemia Type II identified. Open symbols, clinically unaffected subjects; large numbers of half blackened symbols are heterozygous, the arrow with full blackened symbols are indicates the proband affected with RCM type II; cross open symbols are died individuals.
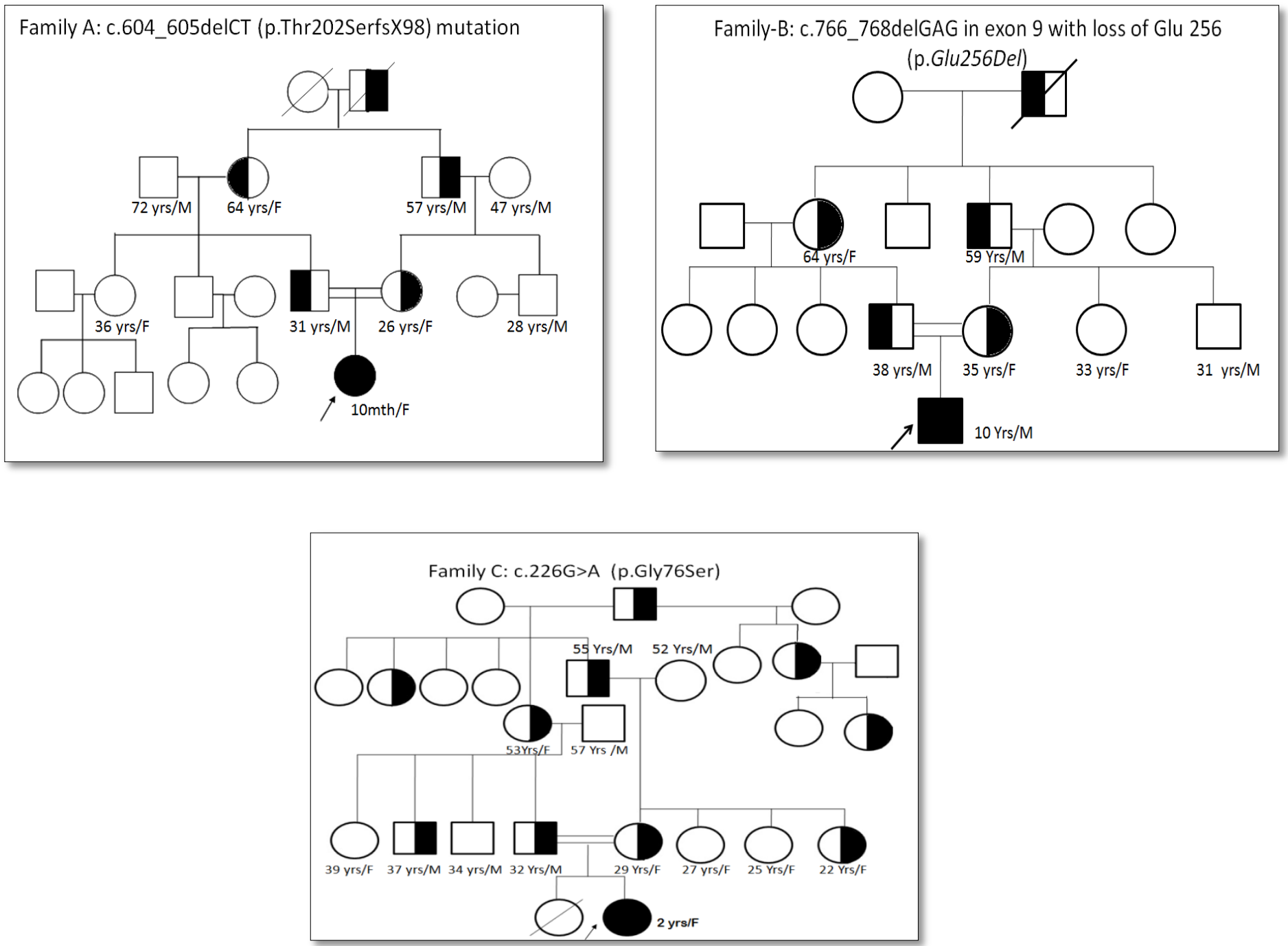


\section{JMSCR Vol||06||Issue||06||Page 626-636||June}

Figure-2: Electropherogram of automated sequencing A) DNA sequence reveals homozygous c.606-607CT two nucleotide deletion in family A, B) c.766-768GAG three base deletion in family B, resulting in frameshift and subsequent chain termination in the Family A, B where as missense homozygous mutation c. $226 \mathrm{G}>\mathrm{A}$ in family $\mathrm{C}$.
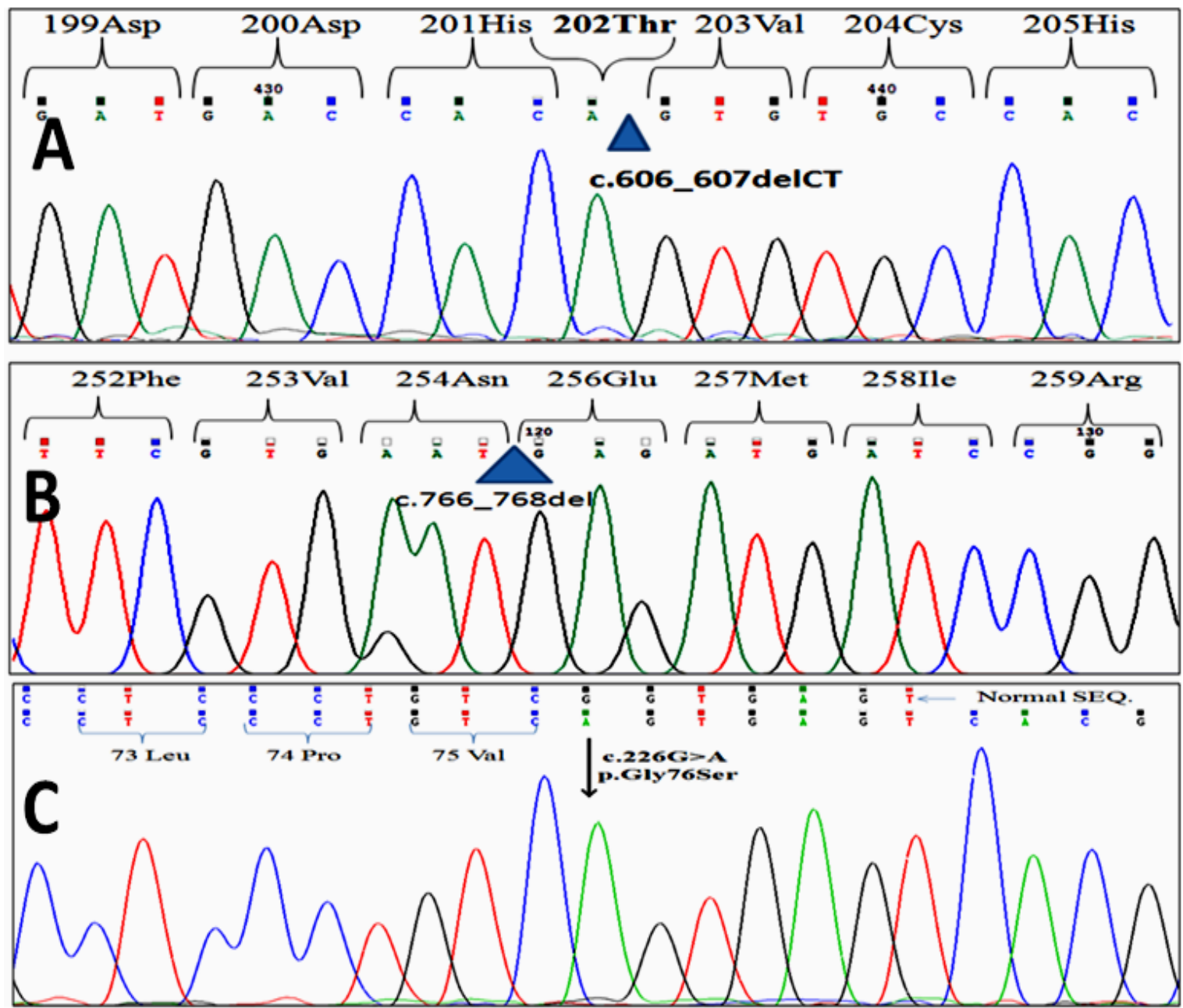

\section{Financial Support and Sponsorship}

This work was supported by the Extramural Research Program of the Council of Scientific and Industrial Research, New Delhi.

\section{Conflict of Interest}

The authors declare no conflict of interest.

\section{Acknowledgment}

The Author thanks the all the parents of the index case. This study was supported by the Indian Council of Medical Research, New Delhi.

\section{References}

1. E. $\mathrm{R}$ Jaffe. Hereditary methemoglobinemias associated with abnormalities in the metabolism of erythrocytes. American
Journal of Medicine, 41 (1996), pp. 786798.

2. M. J. Percy, N.V. McFerran, \& T. R. Lappin, Disorders of oxidized hemoglobin. Blood Reviews, 19 (2005), pp. 6168.

3. J. T. Prchal, X. T. Gregg. Red cell enzymes. Hematology Am Soc Hematol Educ Program. (2005), pp.19-23

4. W. Kugler, A. Pekrun, P. Laspe, B. Erdlenbruch, M. Lakomek. Molecular basis of recessive congenital methemoglobinemia, types I and II: exon skipping and three novel missense mutations in the NADH-cytochrome b5 reductase (diaphorase 1) gene. Human Mutation, 17 (2001), pp. 348. 
5. Q. Gibson. Introduction: congenital methemoglobinemia revisited. Blood, 100 (2002), pp. 3445-3446.

6. J. Dekker, M. H. Eppink, R. Van Zwieten, T. De Rijk, A. F. Remacha, L. K. Law, A.M. Li, K. L. Cheung, W.J. Van Berkel, D. Roos. Seven new mutations in the nicotinamide adenine dinucleotide reduced-cytochrome $b_{5}$ reductase gene leading to methemoglobinemia type I. Blood, 97 (2001), pp. 1106-1114.

7. E. P. Owen, J. Berens, A.M. Marinaki, H. Ipp, E.H. Harley. Recessive congenital methemoglobinaemia type II, a new mutation which causes incorrect splicing in the NADH-cytochrome b5 reductase gene. Journal of Inherited Metabolic Disease, 20 (1997), pp. 610.

8. K. Shirabe, M. T. Landi, M. Takeshita, G. Uziel, E. Fedizzi, N.A. Borgese. A novel point mutation in a $3^{\prime}$ splice site of the NADH-cytochrome b5 reductase gene results in immunologically undetectable enzyme and impaired NADH-dependent ascorbate regeneration in cultured fibroblasts of a patient with type II hereditary methemoglobinemia. American Journal of Human Genetics, 57 (1995), pp. 302-310.

9. R.A. Fisher, S. Povey, M. Bobrow, E. Solomon, Y. Boyd, B. Carritt. Assignment of the DIA1 locus to chromosome 22. Annals of Human Genetics, 41 (1997),pp. 151-155.

10. A. Leroux, C. Junien, J. Kaplan, J. Bamberger. Generalized deficiency of cytochrome $b_{5}$ reductase in congenital methemoglobinaemia with mental retardation. Nature, 258 (1975), pp. 619-620.

11. S. Tomatsu, Y. Kobayashi, Y. Fukumaki, T. Yubisui, T. Orii, Y. Sakaki. The organization and the complete nucleotide sequence of the human NADHcytochrome b5 reductase gene. Gene, 80 (1989), pp. 353-361.
12. E. A. Mannino, T. Pluim, J. Wessler, M.T. Cho, J. Juusola, S.A. Schrier Vergano. Congenital methemoglo-binemia type II in a 5-year-old boy. Clin Case Rep. 7 (2017), pp. 170-178.

13. P.P. Warang, P.S. Kedar, C. Shanmukaiah, K. Ghosh, R.B. Colah. Clinical spectrum and molecular basis of recessive congenital methemoglobinemia in India. Clin Genet. 87 (2015), pp. 62-67.

14. J. Sambrook, E.F. Fritsch, T. Maniatis. Molecular Cloning: A Laboratory Manual. 2nd ed. Cold Spring Harbor Laboratory; Cold Spring Harbor, $\mathrm{NY}$; (1989).

15. H. Hirono. Lipids of myelin, white matter and gray matter in a case of generalized deficiency of cytochrome b5 reductase in congenital methemo-globinemia with mental retardation. Lipids, 15 (1980), pp. 272-275.

16. K.A. Evelyn, H. T. Malloy. Microdetermination of oxyhemoglobin, methemoglobin, and sulfhemoglobin in a single sample of blood. J Biol Chem. 126 (1938), pp. 655.

17. Beutler, E. Red Cell Metabolism. A Manual of Biochemical Methods, 3rd edn. Grune and Stratton, Orlando, FL.(1984).

18. C.M. Aalfs, G.B. Salieb-Beugelaar, R.J. Wanders, M.M. Mannens, F.A. Wijburg. A case of methemoglobinemia type II due to NADH-cytochrome b5 reductase deficiency: determination of the molecular basis. Human Mutation, 16 (2000), pp. 18-22.

19. M.J. Percy, L.J. Crowley, D. Roper, T.J. Vulliamy, D.M. Layton, M.J. Barber. Identification and characterization of the novel FAD-binding lobe G75S mutation in cytochrome b5 reductase: an aid to determining recessive congenital methemoglobinemia status in an infant. Blood Cells, Molecules \& Diseases, 36 (2006), pp. 81-90. 
20. K. Shirabe, Y. Fujimoto, T. Yubisui, M. Takeshita. An in-frame deletion of codon 298 of the NADH-cytochrome b5 reductase gene results in hereditary methemoglobinemia type II (generalized type). A functional implication for the role of the $\mathrm{COOH}$-terminal region of the enzyme. Journal of Biological Chemistry, 269 (1994), pp. 5952-5957.

21. Yilmaz D., Cogulu O., Ozkinay F., and Kavakli K. A novel mutation in the DIAl gene in a patient with methemoglobinemia type II. Am. J. Med. Genet. Part A 2005;133A:101-102.

22. Ewenczyk C., Leroux A., Roubergue A., Laugel V., Afenjar A., Saudubray M., et al. Recessive hereditary methaemoglobinaemia type II: delineation of the clinical spectrum. Brain 2008; 131:760-771.

23. Higasa K., Manabe J., Yubisui T., Sumimoto H., Pung-Amritt P., Tanphaichitr V. S., et al. Molecular basis of hereditary methaemoglo-binaemia, types I and II: two novel mutations in NADH-cytochrome b5 reductase gene. Br. J. Haematol.1998; 103:922-930

24. Kobayashi Y., Fukumaki Y., Yubisui T., Inoue J., and Sakaki Y. Serine-proline replacement at residue 127 of $\mathrm{NADH}$ cytochrome b5 reductase causes hereditary methemoglobinemia, generalized type. Blood 1990; 75:1408-1413.

25. Maran J., Guan Y., Ou C., and Prchal J. T.. Heterogeneity of the molecular biology of methemoglobinemia: a study of eight consecutive patients. Haematologica 2005;90:687-689.

26. Puffenberger E. G., Jinks R. N., Sougnez C., Cibulskis K., Willert R. A., Achilly N. $\mathrm{P}$, et al. Genetic mapping and exome sequencing identify variants associated with five novel diseases. PLoS ONE7: 2012;e28936.
27. Toelle S. P., Boltshauser E., Mossner E., Zurbriggen K., and Eber S.. 2004. Severe neurological impairment in hereditary methaemoglobinaemia type 2. Eur. J. Pediatr. 2004; 163:207-209. 